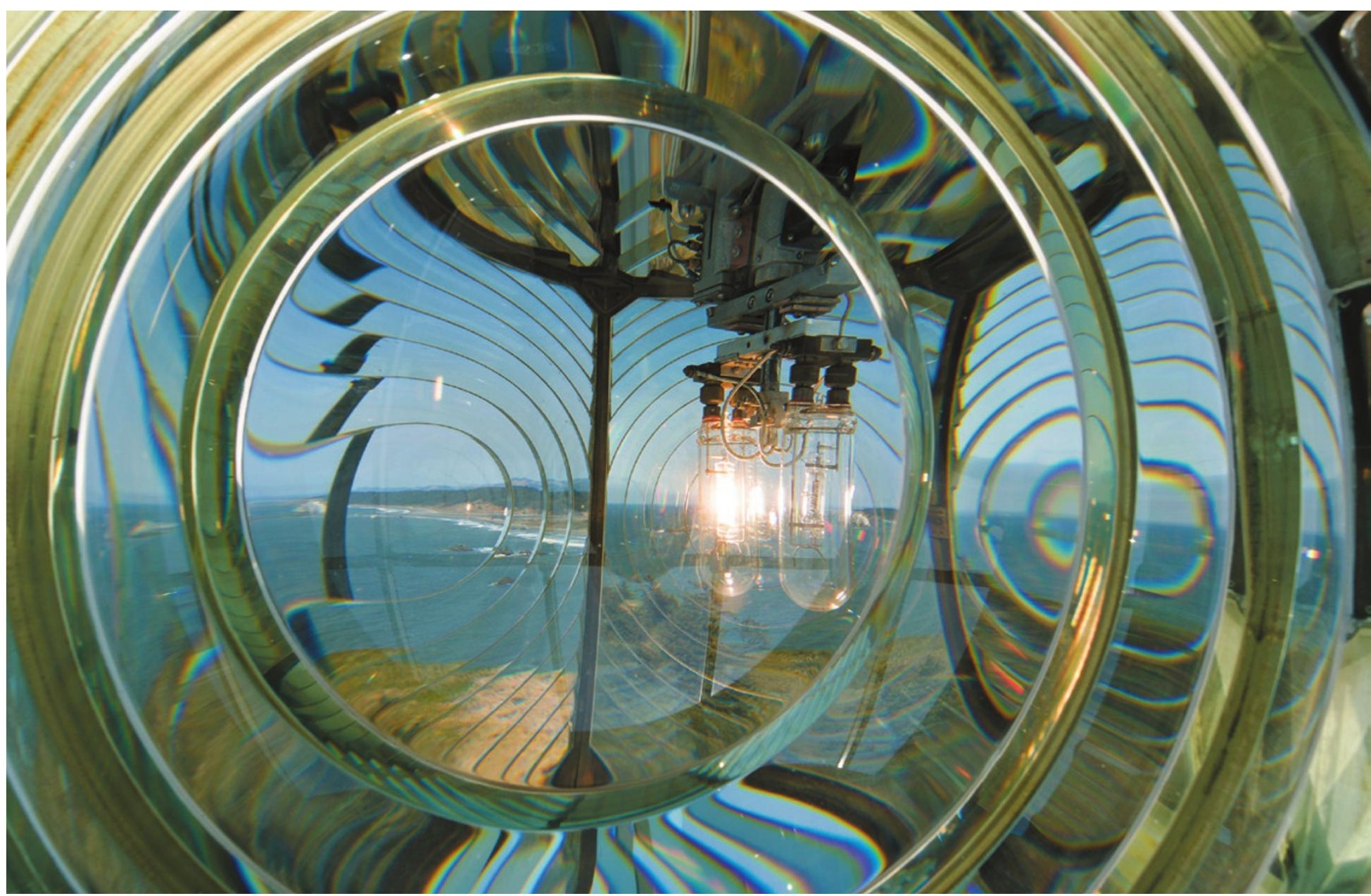

A Fresnel lens inside Cape Blanco Lighthouse in Oregon.

\title{
HISTORY
}

\section{Beam me home}

\section{Joanne Baker enjoys a biography of the doughty French inventor of the bull's-eye} lens, the secret of the modern lighthouse.

A t a remote lighthouse on the English coast, I toured the tower and saw a starfish of beams reaching 20 kilometres across the sea from its revolving glass crown. I imagined the light sucking vast amounts of power from the electric grid, until I saw the bulb: a 20-watt halogen candle smaller than my thumb. It is not in the bulb, but in the glass encasing it, that the power lies.

Nineteenth-century French physicist Augustin Fresnel worked the physical magic of this lens. The light is focused into beams by concentric rings of prisms, each an inch thick and stacked in metre-high panes set into a brass frame. As the apparatus turns on a bed of oil, the beam sweeps across the waves. In A Short Bright Flash, historian

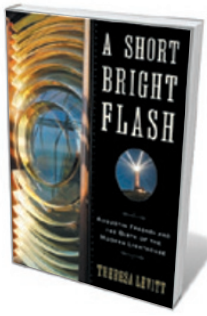

A Short Bright Flash: Augustin Fresnel and the Birth of the Modern Lighthouse

THERESA LEVITT

W. W. Norton: 2013

Theresa Levitt recounts how these lenses came to keep ships safe near the shore and how they spread around the world.

Much trade was conducted by sea in the early nineteenth century and hundreds of vessels ran aground in Europe each year, most at night. Newspapers were filled with stories of shipwrecks and lost crews. France had 20 lighthouses by 1800; Britain, a handful more. These relied on the dim lighting of oil lamps reflected by mirrors, a technology little changed since the first lighthouses of the ancient world - the thirdcentury BC Colossus of Rhodes and Pharos of Alexandria.

Fresnel spent years trying to understand the diffraction of light, first in his spare time while building roads across France for Napoleon, then while jostling with scientific luminaries in Paris. Influenced by physicist and astronomer François Arago - famous for studies on light and magnetism, and helping to discover the planet Neptune - Fresnel came up with controversial extensions to the wave theory of light. In 1819, Arago invited Fresnel to work at the Lighthouse Commission in France, created in 1811 by Napoleon 
to spread 'beacons of light' around his empire. Fresnel saw that lenses would do a better job than mirrors.

The problem was how to capture enough light and focus it. A lens close to a lamp would intercept most of its glare, but forming a beam necessitates bending the rays through a large angle and would require a bulbous lens, which would absorb more of the light. To capture the same amount of light, a thinner lens farther away would have to be larger than could be manufactured at the time. At a demonstration to the commission in 1821, Fresnel placed his bull's-eye lens alongside other reflectors high on the Paris Observatory. The public and commissioners across the city saw that Fresnel's was by far the brightest.

Fresnel built a lens for the country's most prestigious lighthouse at Cordouan, the 'Versailles of the sea' at the mouth of the Gironde estuary near Bordeaux. Installed in July 1823 , its beams could be seen by tall ships up to 33 nautical miles (61 kilometres) away. In 1825, Fresnel revealed a map for 51 lighthouses around the French coast of different sizes and illumination patterns. Two years later he was dead from tuberculosis, and it was left to his brother Leonor to complete the scheme in 1854.

Hundreds of lighthouses with Fresnel lenses had been built by then, from Africa to Brazil. The United States was an exception. Stephen Pleasonton, accountant of the US Lighthouse Establishment, notably refused to sanction the purchase of the lenses, citing cost. US lights burned sperm whale oil at the time and Pleasonton insisted that more efficient lamps were the way to economize.

But with westward expansion and the advent of railways and the telegraph, science and technology rose in the country's esteem. In 1852, Congress passed a bill to create the US Lighthouse Board after several congressmen were stuck in fog on a boat to New York and saw how bad existing lighthouses were. Fresnel lenses were then systematically introduced. Levitt describes how the disabling of lighthouses played a central part in both the American Civil War and the Second World War.

The invention of radar meant that few lighthouses were built and many were decommissioned after the Second World War. Yet working towers retain their Fresnel lenses, which also appear in everything from traffic lights to overhead projectors. Levitt's detailed history is worth ploughing through to see how important scientists and engineers have been in saving sailors' lives. The French saying 'Faire rayonner la France' ('Make France radiant') sums it up. Fresnel indeed lit up his country and the world.

Joanne Baker is senior comment editor at Nature.

\section{Books in brief}

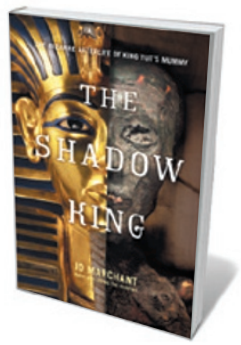

The Shadow King: The Bizarre Afterlife of King Tut's Mummy Jo Marchant DA CAPO PRESS (2013)

The nimbus of romance around Tutankhamun can hide the academic feuds fought over the boy-king's 3,300-year-old mummy. Jo Marchant lifts the golden mask to delve into findings on the enigmatic Egyptian and his relatives. Her rip-roaring story unwraps the science layer by layer, in tandem with the momentous discoveries and the emergence of theories on the ruler's health and parentage. From anatomist Douglas Derry's 1925 autopsy to the X-rays, scans and DNA testing that followed, Marchant lays bare the physical Tut who left behind the crumbling bones.

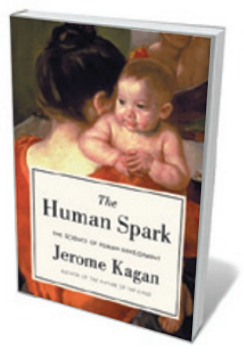

The Human Spark: The Science of Human Development Jerome Kagan BASIC Books (2013)

As developmental psychologist Jerome Kagan points out, physics (starting with Galileo) is 400 years old; the scientific study of children is 150 . This complex field remains in some ways as plastic as the human brain. In his masterful survey, Kagan filters findings in the field. He examines cultural influences, cognition in the first three years of life, morality, the influence of social groupings such as class, and the explosion of mental illness in the young. An authoritative study of the dance of genes and environment in each child as they grow in universally human, and profoundly individual, ways.

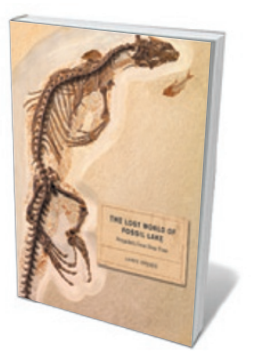

The Lost World of Fossil Lake: Snapshots from Deep Time Lance Grande UNIVERSITY OF CHICAGO PRESS (2013)

Fossil, Wyoming, is a ghost town twice over. Its human population drifted away decades ago. But its most famous denizens disappeared in the Eocene epoch tens of millions of years ago: crocodiles, dragonflies, alligators, horses the size of dogs and 23 species of fish. In this lush, in-depth guide to the area's fossilized fauna, palaeontologist Lance Grande, curator at Chicago's wonderful Field Museum, offers an in-depth portrait of an aquatic community that thrived in a subtropical wonderland of jungles and volcanoes. Beautifully illustrated in colour, including a field guide and atlas.

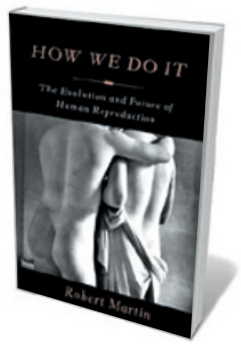

How We Do It: The Evolution and Future of Human Reproduction Robert Martin BASIC BOOKS (2013)

Sex, parenting and fertility - human reproduction is one of the most hotly debated areas of human behaviour. Biological anthropologist Robert Martin wields decades of research to get at the evolutionary facts and inform people's reproductive decisions. He explains why it takes hundreds of millions of sperm to fertilize one egg; the low-down on procreation and conception; and key aspects of caregiving, including a natural history of suckling. Fascinating detours abound - such as the successful, and sensitive, toilet training of six-month-old babies by Kenya's Digo people.

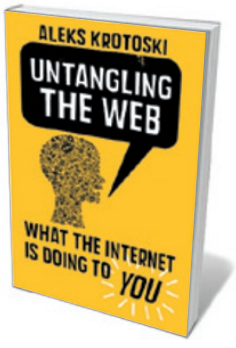

Untangling the Web: What the Internet is Doing to You Aleks Krotoski FABER AND FABER (2013)

Social psychologist Aleks Krotoski is a geek's geek and authority on the World Wide Web - the social experiment that now involves 2 billion people. Is it working wonders or wreaking havoc? Krotoski joins a host of others in attempting to pick over the claims regarding the pros (such as social empowerment) and cons (such as the growth of cults) of the web. Her verdict is mixed: she avers, for example, that the loss of privacy from digital exposure is real, but that the jury is still out on evidence for Internet addiction. Barbara Kiser 